\title{
Strategic Human Resources Information System and Workers' Adaptive Performance of Deposit Money Banks in South-South Nigeria
}

\author{
Constance Obiobraa Oyibo, Prof. M. D. Tamunomiebi, Dr. Soye Peniel Asawo \\ $\mathrm{PhD}$ Candidate at Department of Management, Faculty of Management Sciences, \\ Rivers State University, Port Harcourt \\ Department of Management, Faculty of Management Sciences, \\ Rivers State University, Port Harcourt \\ Department of Management, Faculty of Management Sciences, \\ Rivers State University, Port Harcourt
}

\begin{abstract}
The purpose of this paper was to ascertain the nature of the relationship between strategic human resources information system and workers' adaptive performance of deposit money banks in South-South Nigeria. The research design for the study is the correlational design. The population is comprised of 120 management staff from 5 tier-1 deposit money banks in the South-South of Nigeria. Data was generated using the questionnaire. The Spearman's rank order correlation was adopted in assessing the correlation between strategic human resources information system and measures of workers' adaptive performance adaptive learning, creativity and worker flexibility. Findings show that strategic human resources information system contributes significantly towards adaptive learning, creativity and worker flexibility. It was therefore concluded that organizational actions and decisions that anchor on and utilize strategic human resources information system drives and enhances outcomes of adaptive learning, creativity and worker flexibility, thus leading to workers' adaptive performance within deposit money banks in the South-South of Nigeria.
\end{abstract}

Keywords: Strategic human resource information systems, workers adaptive performance, adaptive learning, creativity, workers flexibility

\section{Introduction}

The environment of business is highly dynamic and volatile. Emerging technologies and other global market factors have necessitated the need for adaptive work actions aimed at driving the survival and competitiveness of organizations both within and outside the context of Africa. In this regard, there has been a growing interest in line with research that addresses workers performance from a more dynamic perspective - especially, that which conceptualizes their capacity for change and responsiveness to the evolving attributes of their industry and context (Horokhiyska, 2019; Lajoie \& Gube, 2018). This interest also borders on identifying the ways in which organizations, through installed human resource systems, technologies and policies, can stimulate workers capacity for change and thus outcomes of adaptive learning, creativity and flexibility at the workplace - with all three factors being measures of workers' adaptive performance.

Lajoie and Gube (2018) noted that the adaptive behaviour of employees is important to the effectiveness of the organization. According to the author, employees who are able to adapt tend to be more inclined towards change and that way, strategically position the organization in ways that advance its competitiveness and performance. This observation is echoed by Grant (2010) who also affirmed that the organization's own level of competence and value is premised on the content of its human resource. This demonstrates the imperatives for workers who are open to learning and willing to try out new approaches and technologies in 
their functions, roles or responsibilities within the workplace. Workers' adaptive performance as such enables improved levels of organizational functionality, generating a variety of creative content and competencies within the organization's workforce - thus leading to organizational preparedness for change.

Studies (Spreitzer, Cameron \& Garrett, 2017; Sarbu, 2018; Jundt, Shoss \& Huang, 2015) have pointed to human resources management practices such as the strategic planning and implementation of policies related to training and development, job design etc. in addressing the adaptive needs of their human resources. However, scant literature has examined the role of strategic human resources related information control mechanisms and platforms in addressing outcomes of workers' adaptive performance. This is as Pani, Panigrahi, Kaur and Chitranshi (2015) observed that organizations with functional database systems on their human resource, often have an edge in terms of control and effective coordination over other organizations that are yet dependent on traditional systems of hardcopy files and documentations. These systems enable functionality effectiveness as they facilitate efficient monitoring and control of the organization's human resources - ensuring the optimality of its application and reconfiguration in line with the changes in the environment.

As a concept yet evolving, workers' adaptive performance has scarcely been researched within the context of strategic human resources information system; despite its noted emphatics in human resources management literature, especially with regards to addressing disruptive technologies and organizational change. This leaves an apparent gap in knowledge and the imperative for research that not only captures the relationship between the variables (strategic human resources information system and workers' adaptive performance) but does that within a developing context such as that of Nigeria. Thus, as a point of departure from previous studies, this paper investigated the relationship between strategic human resources information system and workers' adaptive performance of tier-1 deposit money banks in the South-South of Nigeria.

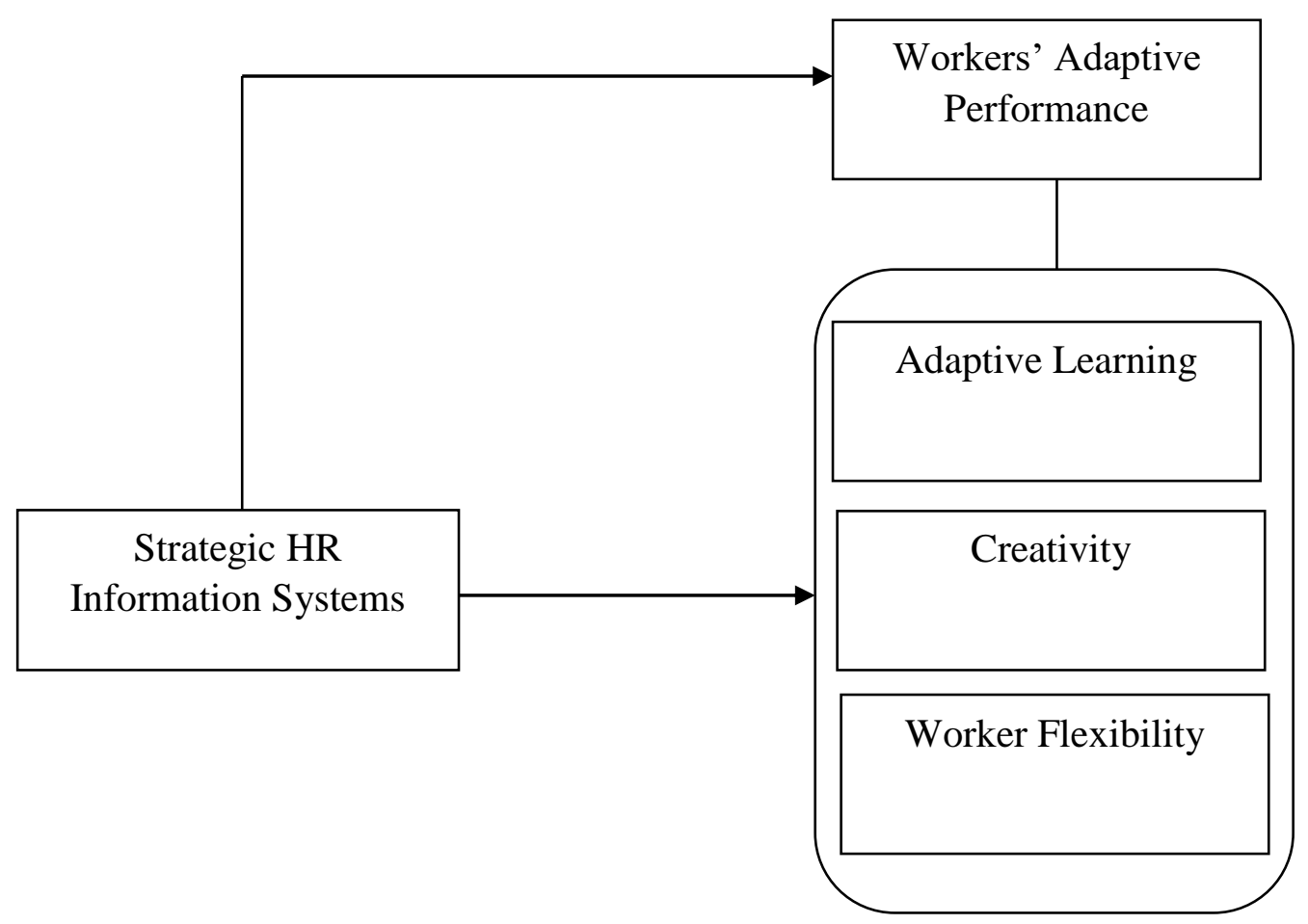

Figure 1: Conceptual framework on strategic human resources information system and workers adaptive performance.

Source: Researchers desk (2021) with measures for workers' adaptive performance adapted from Jundt Shoss and Huang (2015)

Objectives of the Study 
The objectives of this paper are to:

i. Examine the relationship between strategic HR information system and adaptive learning in tier-1 deposit money banks in the South-South of Nigeria.

ii. Examine the relationship between strategic HR information system and creativity in tier-1 deposit money banks in the South-South of Nigeria.

iii. Ascertain the relationship between strategic HR information system and worker flexibility in tier-1 deposit money banks in the South-South of Nigeria.

\section{Research Questions}

The research questions for this paper are as follows:

i. What is the relationship between strategic HR information system and adaptive learning in tier-1 deposit money banks in the South-South of Nigeria?

ii. What is the relationship between strategic HR information system and creativity in tier-1 deposit money banks in the South-South of Nigeria?

iii. What is the relationship between strategic HR information system and worker flexibility in tier-1 deposit money banks in the South-South of Nigeria?

\section{Review of Literature}

\section{Theoretical Foundation (Human Capital Theory)}

The theoretical foundation for this paper is the human capital theory. The human capital theory follows a thought-line which recognizes and advances a position on the value of workers, especially with regards to increasing their earning capacity through investments in their development. Alnachef and Alhaijar (2015) argued that concerns about the development of the organization's human capital are mostly based on (a) enhancing its value to the organization (b) enhancing its earnings and revenue generating capacity, and (c) ensuring it provides optimal support and is well aligned for the attainment of the organization's purpose. The human capital theory of the organization is therefore central to understanding the employer-employee relations and exchanges within the organization. Horokhivska (2019) argued that the transformation of the worker through learning opportunities and occasions of development programs should follow a particular standard or benchmark - such that equate to the underlying characteristics of the environment of the organization.

\section{Strategic HR information system}

Strategic human resources information system is concerned with aspects of the organization's database management system which facilitates the effective forecasting, planning, and development of the organization's human resource in view of the changes or emerging qualities of its environment (Adelekan, 2016). Strategic HR information system provides the link and bridge between the organization's environment and the content of its human resource. It is as such essential in ensuring that there is a harmonic and well aligned approach through which the organization is able to provide value to its market, based on the configuring of the content of its workforce to suit the features of its market (Kumari \& Dubey, 2018). Its primary purpose is to keep top management well informed about labour resources and workforce planning. It provides information that makes the process of HR planning, control, decision-making and policy formulation smooth and efficient (Irum \& Yadav, 2019). Major types of strategic HRIS include information systems that support workforce planning and specialized HRIS software which enables the overall HR domain to function seamlessly.

\section{Workers' Adaptive Performance}

Research has shown that adaptive performance is a kind of job performance that is different from task performance and organizational citizenship behaviour (Sarbu, 2018). Sivatte and Guadamillas (2013) has defined adaptive performance as the ability to adjust one's behaviour with the requirements of the environment in a new situation. Spreitzer, Camron and Garrett (2017) argue that workers' adaptive performance includes behaviours that help the individuals when faced with change, knowledge transfer from one task to another, and new job requirements. Recently, Bowers, Merritt, \& Rimm-Kaufman, (2020) have defined workers' adaptive performance as the recognition of need or opportunities to actively increase 
competence and good behaviour in response to existing or anticipated changes, and development of qualifications and ability to adapt effectively in the workplace. Workers' adaptive performance is concerned with an employee's capability to adapt or conform to dynamic work environments (Charbonnier-Voirin and Roussel, 2012). Workers adjust their behaviour to fit into the new work environment to express adaptive performance.

Adaptive learning: This refers to the individual's openness to new knowledge and ideas. This is demonstrated through the individual or workers' capacity to absorb and express such knowledge in their work or roles within the workplace (Jundt et al, 2015). It is concerned with the learning of new work tasks, technologies and procedures and involves the capacity of an employee to learn new ways of performing his tasks or learning different skill-sets to perform a new task. The dynamic nature of today's business environment has made adaptive learning very vital as employees are faced with innovations and advancements in technology that compels them to learn new skills or be made obsolete. The dynamic environment of business has made it mandatory for employees to learn continuously if they want to adapt. Adaptive learning is a strong indicator of workers' adaptive performance since it reflects the change openness and action of the worker. Jundt et al (2015) argued that learning precedes workers' skill development or behavioural modifications in line with the demands or expectations of the environment. Adaptive learning thus suggests a disposition towards new information and also the willingness and capacity to apply such in one's work.

Creativity: The concept of creativity is highly debatable (Zhang, Waldman, Han, \& Li, 2015). Not only because it is context-based (implying novelty based on audience or time factor), but also because it is relative in terms of the dominant interpretations or value of the product or service in question. Creativity according to Jundt et al (2015) describes the expression of uniqueness or distinctiveness in thinking or actions. To be creative means to have the capacity to think differently or act differently in a manner that is dissimilar to the norm but yet considered as welcoming and acceptable due to the substantiality of its contributions. Creative employees are therefore workers who have the capacity for novelty and newness in their actions and behaviour in the workplace (Jundt et al, 2015). Creativity is an important attribute for employees to possess if they are to successfully solve novel and unfamiliar problems they will encounter as a result of the dynamic and changing business environment.

Worker flexibility: This describes the worker's capacity to function effectively within a variety of roles or units within the workplace (Jundt et al, 2015). This is mostly possible where workers show interest and are willing to learn about the features and activities of other units or groups within the organization - and in that manner, demonstrate or express sincere interest in acquiring and strengthening a variety of skill sets that make them useful, not only to one department or unit, but to a variety of units or functions within the workplace. This enhances their value and relevance to the organization, thus driving their functionality and placement within the workplace (Jundt et al, 2015; Salolomo \& Agbaeze, 2019). Worker flexibility advances the worker's relevance and value within the organization. It is a reflection of their openness towards change and their ability to cope and thrive during related change events.

\section{Strategic HR information system and workers' adaptive performance}

Strategic HR information system provides data for strategic decision making on human resource forecasting and planning (Silva \& Lima, 2018). This aspect of information management is more concerned with matching organizational values and behaviour with the overarching features and attributes of the environment. Jahan (2014) argued that strategic HR information system in its focus details the ways and patterns through which the human resource of the organization can be structured to accommodate the emerging features, increasingly characterizing their environment.

Strategic HR information system follows a deliberate course of action in driving the relationships, communication forms, roles and structure of the organization towards the direction of the organization's market - thus emphasizing on particular sets of skills and values necessary for the human resource of the organization. It is as Parvin (2015) observed, a strong indicator of the organization's cognition of its situation and environment. However, the absence of empirical literature on the relationship between 
strategic HR information system and workers' adaptive performance is such that impedes on the development of knowledge in that area, particularly as it affects most developing regions. This paper thus hypothesized as follows:

$\mathrm{HO}_{1}$ : There is no significant relationship between strategic HR information system and adaptive learning in tier-1 deposit money banks in the South-South of Nigeria.

$\mathrm{HO}_{2}$ : There is no significant relationship between strategic HR information system and creativity in tier-1 deposit money banks in the South-South of Nigeria

$\mathrm{HO}_{3}$ : There is no significant relationship between strategic HR information system and worker flexibility in tier-1 deposit money banks in the South-South of Nigeria

\section{Methodology}

The research design adopted for this investigation is the correlational design (Mutch, 2005). As a form of descriptive research, the correlational design focuses on understanding the nature of interaction between assumed predictor and criterion variables in a relationship and on that basis provide facts that serve in related theory validation and development. While there are a total of 22 deposit money banks in Nigeria, the accessible population for this study is delimited to the state headquarter branches of five (5) tier 1 deposit money banks in South-South Nigeria, which comprise six states - Akwa Ibom, Bayelsa, Cross River, Edo, Delta, and Rivers States. Measurement unit for the population comprise the human resource managers, as well as three other managers of key strategic units (Marketing, Customer Services and Accounting/Finance) which could be considered as prevalent within all five tier-1 deposit money banks in the South-South of Nigeria. Hence the population for the study is 120 management staff from the five banks (https://www.cbn.gov.ng/Supervision/Inst-DM.asp).

Given the population size of 120 for this study, a census was considered as adequate. This choice also bordered on the position of Newby (2010) who asserted that census studies have lower levels of error outcomes and as such are more precise in their estimates with regards to the population. Data for this investigation is mostly comprised of primary data which was sourced from the participants of the study. This was accomplished through the use of the structured questionnaire, which was distributed manually through established personnel contacts within each of the designated headquarters of the tier-1 deposit money banks of interest in each State. Table 1 below demonstrates the reliability result for the study.

Table 1: Distribution for Cronbach alpha reliability for the study

\begin{tabular}{|l|l|l|}
\hline Variables & Items & Main Study \\
\hline Strategic HR information system & 4 & 0.804 \\
\hline Adaptive Learning & 4 & 0.921 \\
\hline Creativity & 4 & 0.793 \\
\hline Worker Flexibility & 4 & 0.744 \\
\hline
\end{tabular}

Source: Research Data, 2021

\section{Data Presentation and Analysis}

Following the population size for the study, 120 copies were distributed in the fieldwork; however, only 101 copies were successfully retrieved, cleaned and utilized in the investigation.

Table 2: Summary distribution for the variables of the study

\begin{tabular}{|l|c|c|c|c|c|c|c|c|}
\hline & $\mathrm{N}$ & \multicolumn{2}{|c|}{ Mean } & $\begin{array}{c}\text { Std. } \\
\text { Deviation }\end{array}$ & \multicolumn{2}{c|}{ Skewness } & \multicolumn{2}{c|}{ Kurtosis } \\
\cline { 2 - 9 } & $\begin{array}{c}\text { Statisti } \\
\mathrm{C}\end{array}$ & $\begin{array}{c}\text { Statisti } \\
\mathrm{C}\end{array}$ & $\begin{array}{c}\text { Std. } \\
\text { Error }\end{array}$ & Statistic & $\begin{array}{c}\text { Statisti } \\
\mathrm{C}\end{array}$ & $\begin{array}{c}\text { Std. } \\
\text { Error }\end{array}$ & $\begin{array}{c}\text { Statisti } \\
\mathrm{C}\end{array}$ & $\begin{array}{c}\text { Std. } \\
\text { Error }\end{array}$ \\
\hline Strategic & 101 & 3.3267 & .09192 & .92381 & -1.070 & .240 & .398 & .476 \\
\hline
\end{tabular}




\begin{tabular}{|l|r|r|r|r|r|r|r|r|}
\hline Adapt & 101 & 3.5050 & .10341 & 1.03922 & -.924 & .240 & .088 & .476 \\
\hline Creativity & 101 & 3.7153 & .10484 & 1.05358 & -1.157 & .240 & .204 & .476 \\
\hline Flexibility & 101 & 3.4406 & .09870 & .99194 & -.937 & .240 & .108 & .476 \\
\hline $\begin{array}{l}\text { Valid N } \\
\text { (listwise) }\end{array}$ & 101 & & & & & & & \\
\hline
\end{tabular}

Source: Research Data, 2021

Table 2 illustrates the summary of the descriptive statistics on the variables (strategic human resources information system, adaptive learning, creativity and worker flexibility). The four variables are revealed to have high mean scores which indicate agreement and affirmation by the participants to the manifestations and substantiality of the four variables within their respective organizations.

Table 3: Test for Hypotheses

\begin{tabular}{|c|c|c|c|c|c|c|}
\hline & & & $\begin{array}{c}\text { Strategi } \\
\text { C }\end{array}$ & Adapt & $\begin{array}{c}\text { Creativit } \\
\mathrm{y}\end{array}$ & $\begin{array}{c}\text { Flexibilit } \\
y\end{array}$ \\
\hline \multirow[t]{12}{*}{ Spearman's rho } & \multirow{3}{*}{$\begin{array}{l}\text { Strategi } \\
\mathrm{C}\end{array}$} & Correlation Coefficient & 1.000 & $.932^{*}$ & $.566^{\pi}$ & \\
\hline & & Sig. (2-tailed) & . & .000 & .000 & .000 \\
\hline & & $\mathrm{N}$ & 101 & 101 & 101 & 101 \\
\hline & \multirow[t]{3}{*}{ Adapt } & Correlation Coefficient & .932 & 1.000 & $.706^{\pi m}$ & $.752^{\pi}$ \\
\hline & & Sig. (2-tailed) & .000 & . & .000 & .000 \\
\hline & & $\mathrm{N}$ & 101 & 101 & 101 & 101 \\
\hline & \multirow{3}{*}{$\begin{array}{l}\text { Creativit } \\
\mathrm{y}\end{array}$} & Correlation Coefficient & .566 & .706 & 1.000 & .601 \\
\hline & & Sig. (2-tailed) & .000 & .000 & . & .000 \\
\hline & & $\mathrm{N}$ & 101 & 101 & 101 & 101 \\
\hline & \multirow{3}{*}{$\begin{array}{l}\text { Flexibilit } \\
y\end{array}$} & Correlation Coefficient & $.781^{\circ}$ & .752 & $.601^{\circ}$ & 1.000 \\
\hline & & Sig. (2-tailed) & .000 & .000 & .000 & . \\
\hline & & $\mathrm{N}$ & 101 & 101 & 101 & 101 \\
\hline
\end{tabular}

Source: Research Data, 2021

i. What is the relationship between strategic HR information system and adaptive learning in tier-1 deposit money banks in the South-South of Nigeria?

ii. What is the relationship between strategic HR information system and creativity in tier-1 deposit money banks in the South-South of Nigeria?

iii. What is the relationship between strategic HR information system and worker flexibility in tier-1 deposit money banks in the South-South of Nigeria?

The analysis shows that at a rho $=0.932$, strategic HR information system strongly contributes towards adaptive learning; at a rho $=0.566$, strategic HR information system moderately correlates with creativity and at a rho $=0.781$, strategic HR information system strongly relates with flexibility. The results reveal that the extent and strength of the relationship between strategic HR information system and the measures of workers' adaptive performance vary from moderate to strong; nonetheless, the relationship between strategic HR information system and workers' adaptive performance is a substantial and positive one.

Hypothesis $\mathrm{HO}_{1}$ : there is no significant relationship between strategic HR information system and adaptive learning

The relationship between strategic HR information system and adaptive learning is revealed to be significant given the observed relationship between the variables $(\mathrm{Pv}=0.000)$. The correlation value shows a strong and significant relationship between both variables even at a $99 \%$ confidence interval also implying a 0.01 level of significance. The hypothesis of no relationship is rejected based on the decision rule of $\mathrm{P}<0.05$. We therefore reject the null hypothesis and restate that strategic HR information system significantly and positively contributes highly towards adaptive learning.

Hypothesis $\mathrm{HO}_{2}$ : there is no significant relationship between strategic HR information system and creativity 
The relationship between strategic HR information system and creativity is revealed to be significant given the observed relationship between the variables $(\mathrm{Pv}=0.000)$. The correlation value shows a moderate and significant relationship between both variables even at a $99 \%$ confidence interval also implying a 0.01 level of significance. The hypothesis of no relationship is rejected based on the decision rule of $\mathrm{P}<0.05$. We therefore reject the null hypothesis and restate that strategic HR information system significantly and positively contributes at a moderate level towards adaptive learning.

Hypothesis $\mathrm{HO}_{3}$ : there is no significant relationship between strategic HR information system and worker flexibility

The relationship between strategic HR information system and worker flexibility is revealed to be significant given the observed relationship between the variables $(\mathrm{Pv}=0.000)$. The correlation value shows a strong and significant relationship between both variables even at a $99 \%$ confidence interval also implying a 0.01 level of significance. The hypothesis of no relationship is rejected based on the decision rule of $\mathrm{P}<0.05$. We therefore reject the null hypothesis and restate that strategic HR information system significantly and positively contributes strongly towards worker flexibility.

\section{Discussion of The Findings}

In view of the significance of the relationship between strategic HR information system and workers' adaptive performance, this study agrees with and in that vein affirms the position of previous studies (Alipour \& Mahdi, 2010; Chandan \& Urhuogo, 2012) in that it identifies strategic HR information system as a substantial antecedent of workers' adaptive performance - thus advancing the imperatives of the regularization of such systems in the functionality of the organization. Siami (2006) argued that strategic HR information systems are essential for work relations and performance outcomes at both the individual and organizational level. The author further noted that the performance of competitive firms is associated with strategic HR information system. Siami (2006) further observed that investment in strategic HR information system has enhanced outcomes of efficiency and effectiveness within organizations - thus improving work conditions and customer service delivery, market expansion and information management among competitive firms.

Strategic HR information system plays a critical role in giving an organization a competitive edge and also improves the performance and competitiveness of the organization as it allows and encourages the innovation of unique products and service forms. This may lead to first mover advantage, reduction in operation costs by increasing efficiency, development of strategic alliances with key customers, suppliers, consultants and other partners, plus differentiation of products and services, which contributes to improvement of the processes and operations of organizations (Alipour \& Mahdi, 2010).

Strategic HR information system is as such vital and in every sense crucial to the wellbeing of the organization. Given the externally oriented ideologies, which characterize strategic management in banking industries across the world, strategic HR information system helps them circumnavigate through the everchanging environment in order to be efficient and effective in the long run (Muraleedharan, 2014). This is as studies argue that, for organizations to cope, thrive and survive in the face of increasing turbulence with uncertainty in the changing business environment, technology integration in the system must be emphasized across the organization (Salwe, Ahmed, Aloufi, \& Kabir, 2010). To persevere and prevail in today's turbulent surroundings, organizations - especially banks, must therefore focus on driving their functions and services through improved technology integration such as necessitated by strategic JR information system (Salwe et al, 2010).

\section{Conclusion}

This paper affirms the significance of strategic human resource information system in enabling improved levels of workers' adaptive performance - thus in line with the evidence generated, this study concludes that organizational actions and decisions that anchor on and utilize strategic HR information system drives and enhances outcomes of adaptive learning, creativity and worker flexibility, thus leading to workers' adaptive performance within deposit money banks in the South-South of Nigeria 


\section{References}

1. Adelekan, S. A. (2016). The impact of organizational culture on innovation capability of SMEs. International Journal of Economics, Commerce and Management. 6(9), 158- 181.

2. Alipour, M. \& Salehi, M., (2010). E-banking in emerging economy: Empirical evidence of Iran. International Journal of Economics and Finance, 2(1), 201-209.

3. Alnachef, T. H. \& Alhajjar, A. A. (2015). Effect of human capital on organizational performance: A literature review. International Journal of Science and Research, 6(8), $1154-1158$.

4. Bowers, N., Merritt, E., \& Rimm-Kaufman, S. (2020). Exploring teacher adaptive expertise in the context of elementary school science reforms. Journal of Science Teacher Education, 31(1), 34-55.

5. Chandan, H. C., \& Urhuogo, I. (2012). Organisational challenges for innovation in information systems. SAIS 2012 Proceedings, 8. https://aisel.aisnet.org/sais2012/8. Accessed $20^{\text {th }}$ July, 2021.

6. Charbonnier-Voirin, A., \& Roussel, P. (2012). Adaptive performance: A new scale to measure individual performance in organizations. Canadian Journal of Administrative Sciences, 29(3), 280 293.

7. Grant R. M. (2010). Contemporary strategy analysis. Oxford, UK: John Wiley and Sons.

8. Horokhivska, T. (2019). Characteristics of developing professional-pedagogical competency in university teachers in the context of Polish experience. Comparative Professional Pedagogy, 9(3), $37-43$.

9. Irum, A. \& Yadav, R. S. (2019). Human resource information systems: A strategic contribution to HRM. Strategic Direction, 35(10), 4-6.

10. Jahan, S. (2014). Human resources information system: A theoretical perspective. Journal of Human Resource and Sustainability Studies (2),33-39.

11. Jundt, D. K., Shoss, M. K., \& Huang, J. L. (2015). Individual adaptive performance in organizations: A review. Journal of Organizational Behaviour, 36, 56-71.

12. Kumari, P., \& Dubey, P. (2018). Employee performance and their organizational commitment in relation to HRM practices: A literature review. IOSR Journal of Business and Management (IOSRJBM), 5(12), 56-67.

13. Lajoie S. P., \& Gube M., (2018). Adaptive expertise in medical education: Accelerating learning trajectories by fostering self-regulated learning. Medical Teacher, 40, 809-812.

14. Muralidharan, S., Box, M. S., Sedivy, E., Wigge, P., Weigel, D., \& Rowan, B. A. (2014). Modern banking theory and practice. Deilhi: PHI Learning.

15. Mutch, C. (2005) Doing educational research: A practitioner's guide to getting started. Wellington: New Zealand Council for Educational Research Press.

16. Newby, P. (2010). Research methods for education. London, UK: Pearson Education.

17. Pani, S., Panigrahi, S., Kaur, R., Chitranshi, J. (2015). Effectiveness of human resources information system on HR functions of an organization, Management Dynamics, 15(2), 112-135.

18. Parvin, A. (2015). Human resources information system of Bangladesh Jute Research Institute. International Journal of Information Technology and Business Management, 33(1), 33-40.

19. Salolomo, B., \& Agbaeze, E. K. (2019). Effect of work-life balance on performance of money deposit banks in South-South Nigeria. Management Science Letters, 535-548

20. Salwe, A., Ahmed, M., Aloufi, K., Kabir, M., (2010). Strategic information systems alignment: Alignment of IS/IT with business strategy. Journal of Information Processing Systems, (6), 1-7.

21. Sarbu, M. (2018). The role of telecommuting for work-family conflict among German employees. Research in Transportation Economics, 70, 37-51.

22. Siam, A. Z. (2006). Role of the electronic banking services on the profits of Jordanian banks. American Journal of Applied Sciences, 3(9), 1999-.2004.

23. Silva, M. A., \& Lima, C. G. S. (2018). The Role of Information systems in human resources management. Intech Open Journals, 4, 113-126.

24. Sivatte, I. D., \& Guadamillas, F. (2013). Antecedents and outcomes of implementing flexibility policies in organizations. The International Journal of Human Resource Management, 24(7), 13271345 . 
25. Spreitzer, G. M., Cameron, L., \& Garrett, L. (2017). Alternative work arrangements: Two images of the new world of work. Annual Review of Organizational Psychology and Organizational Behaviour, 4(1), 473-499.

26. Zhang, Y., Waldman, D. A., Han, Y.L., \& Li, X. B. (2015). Paradoxical leader behaviours in people management: Antecedents and consequences. Academy of Management Journal, 58, 538-566. 